\title{
Clinical Outcome of Sandwich Technique Along with Locking Plate Augmentation in Giant Cell Tumoraround Knee.
}

\author{
Dr Saikat Sau ${ }^{1}$, Dr Avijit Basak ${ }^{2}$ \\ ${ }^{I}$ Ms-Ortho,Dnb-Ortho,Mnams,Diploma In Tissue Banking-Singapore Rmo Cum Clinical Tutor At \\ Medical College ,Kolkata, Department Of Orthopaedics \\ ${ }^{2}$ Ms- Ortho Rmo Cum Clinical Tutor At Sskm, Kolkata, Department Of Orthopaedics
}

\begin{abstract}
Abstruct
Introduction:Giant cell tumor is very common around knee.As per conventional treatment we use to do extended curettage and sandwich method for recostuction, but early weight bear in those cases is not possible.As aresultstiffness,collapse of articular surface, and delayed pathological fractures are the possible complications.In this study we have done prospective study after extended curettage and sandwich with locking plate augmentation.

After locking plate augmentation in same sitting help us to allow early waight bear and movement, decrease chance of pathological fracture and better clinical outcome.

Material and method-Eighteen patients who had giant-cell tumor of bone and were managed with extended curettage and reconstruction using either bone grafting or sandwich technique between July 2012 and December 2016 were studied. Aggressive curettage was done with the use of various, at Institute of post graduate education \&research KOLKATA, west Bengal. We had used adjuvants like high speed burr, hydrogen peroxide along with locking plate augmentation for all cases.

Results: After a median duration of follow-up of 14.5 months, the average MSTS score at final follow up was 24.59. Age, gender, grade of tumor, technique and recurrence had no significant effect on the eventual functional outcome achieved by the patients.No complication found in our study after using locking plate.Rather all patients are very satisfied with neer full range of movement of knee.

Conclusions: We concluded a good to excellent functional outcome without compromise of prognosis, can be achieved by using locking plate augmented sandwich technique following extended curettage.Most patients could resume their previous work and reach the earlier level of physical activities. Early mobilization hepls to achieve good range of movement. Alonger duration of follow-up of a larger group of patients is necessary to study the recurrence rates.
\end{abstract}

Keywords: giant cell tumor, extended curettage, Locking plate.

\section{Introduction}

Giant cell tumor welknown as locally aggressive tumor(2,3,4,5,) of bone may undergo malignant transformation.(6) It represents $4-5 \%$ of primary bone tumors and $20 \%$ of biopsy concluded benign bone tumours.(7) There is a slight female predominance( 8 ) with a peak incidence in young adults aged 20-40 years(.2 $, 8,9,10)$.The most frequent sites are lower end femur, proximal tibia, lower end radius(11) and proximal humerus.(8,12) The treatment of GCT aims to eradicate the tumor tissue, reconstruct the bone defect, and restore a functional limb. When formulating a plan for local control of GCT, the treatment options are extended curettage $(2,4,12,13,14)$ and reconstruction with bone graft or sandwich technique 15,16 and an en-bloc resection. $(2,4,13,17,18)$.

En-bloc resection(11) is carried out if the tumor is large enough to involve a wide area of surrounding soft tissue or when the articular cartilage is largely damaged, there is inadequate bone stock post curettage and when resection results in no significant morbidity as proximal fibula and flat bones.(18,19)To reduce local recurrence after curettage, various methods have been tried like the use of $\operatorname{burr}(20)$, phenol(3, 7, 21, 22), electrocautery(23), cryotherapy $(5,22)$, hydrogen peroxide(3, 23, ) ringer lactate and argon laser(24)as adjuvant therapies. Reconstruction of the bone void is done using either autograft bone20, 25, 26, 27; allograft bone(20, $25,26,27)$ and polymethyl methacrylate bone cement (PMMA).(4, 21, 26, 28, 29, 30,31) However it is very well documented that local tumor control depends on how thoroughly the tumor tissue has been excised.(20) Although a marginal or wide excision of the involved bone is curative if contamination is avoided with reported recurrence rate of $0-32 \%(32,33,34$, ) It is associated with reconstruction and disability problems. Recurrence rates after intralesional procedures have ranged from $30-52 \%$ irrespective of use of adjuvants. $(20,23,25,26,27$, $28,29,32,33,35)$ Although a lot of studies do define the cure rate and focus on

the recurrence and other surgical variables, there exists a lack of studies on the functional outcome after treatment of GCT. This study aims to find out the early functional outcomes after extended curettage and 
reconstruction using either bone graft or sandwich technique with internal fixation. we are discussing the outcome after sandwich technique reconstruction augment with locking plate.we can allow

\section{Material And Method}

Between July 2012 and December 2016, a total of 18 patients with giant cell tumor (GCT) of the long bones have been treated at the SSKM, ipgmer kolkata. All patients were evaluated by clinical examination, local plain X-ray, chest X-ray, computerized tomography and magnetic resonance imaging. Biopsy was taken in all cases to confirm the diagnosis and to define the histological grade of the tumor. The lesions were classified according to the radiographic parameters considered by Campanacci et al ${ }^{(7)}$ into grade I, II or III. Different surgical modalities were used including: curettage with bone grafting; curettage with bone cement filling; Curettage and Adjuvant with bone cement and / or Bone graft; wide surgical resection; Curettage was done through a large cortical window by the manual curette and by the dental burr in all cases. The adjuvant local therapy used in our cases were hydrogen peroxide $\left(\mathrm{H}_{2} \mathrm{O}_{2}\right)$ and electrical cautery. Selection of the surgical technique was based on the site and size of the lesion, soft tissue involvement (intra- or extra-compartmental), tumor grade (histological and radiological). Patients were clinically and radiologically a minimum of two years (2-4 detect local recurrence, pulmonary metastasis, local of surgery and to assess the functional outcomes the patients.

\section{Operative technique}

We used to do core needle biopsy for all cases.during final help us to discard the biopsy tract by sacrificing very small tissuue ,after proper skin flap Adequate exposure wasachieved large cortical window by electric saw to access thetumor so as having to curette under overhangingshelves or ridges of bone. mirror was used whichhelped for better visualization. The part thecavity which is composed of soft tissue or a thin bony

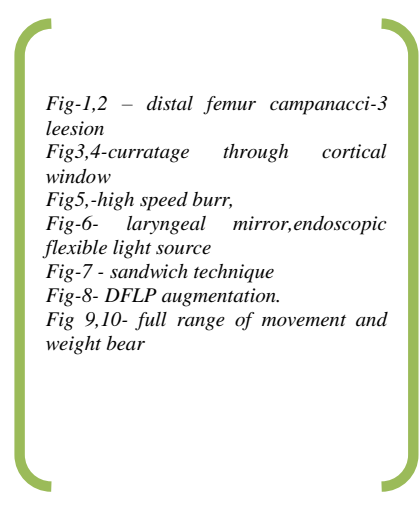
followed-up, years) to complications

operation it amount of by making a to avoid A dental of the wall of shellwas excised.

Multiple angled curettes helped to identify andaccess small pockets of residual disease which may otherwiseresult in recurrence. The remaining cristae and septa in thecavity were excised

flexible cable light soures. When the wall of the cavity containsmany small holes caused by local invasion of the tumour, eachhole should be meticulously cleared.

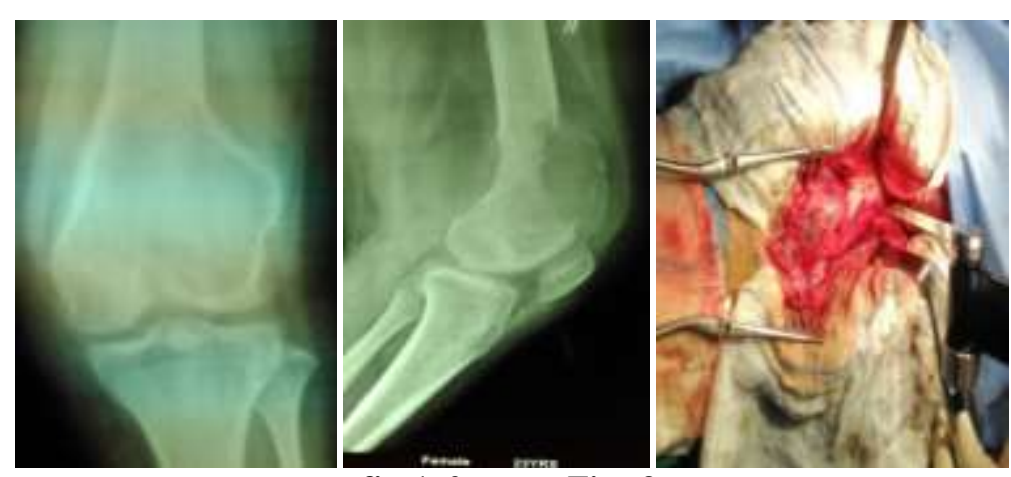

fig-1.,2. $\quad$ Fig--3

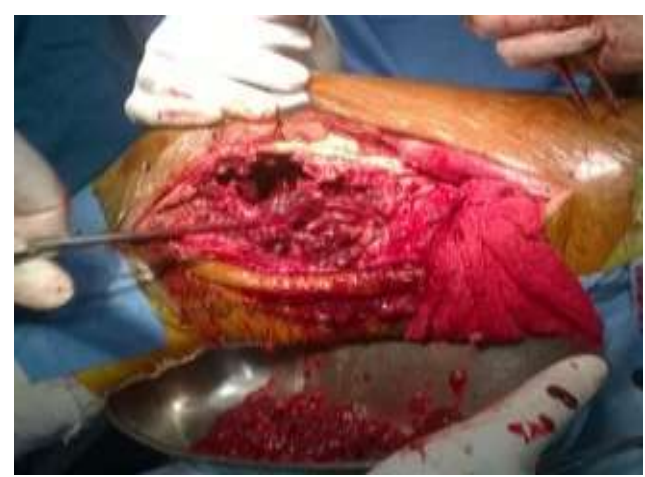

fig-4 

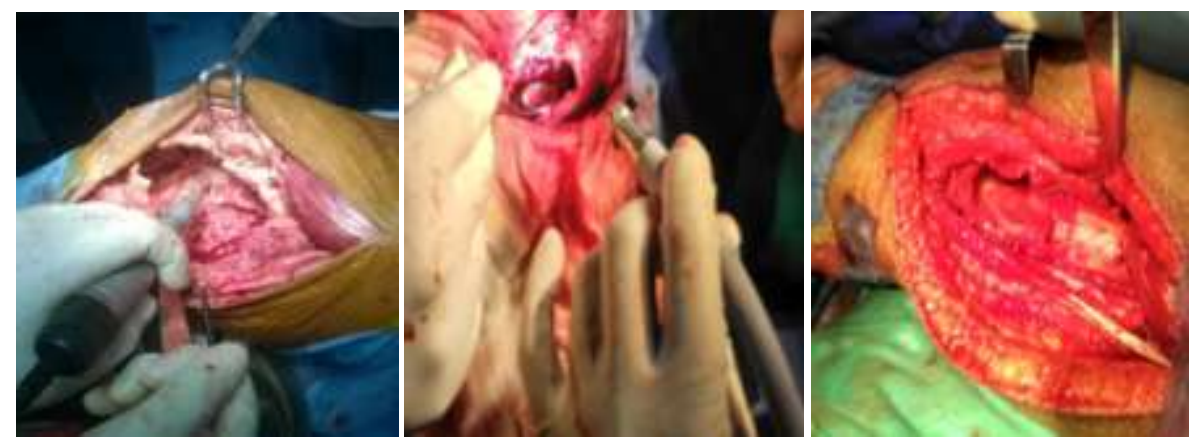

fig-5fig-6fig-7
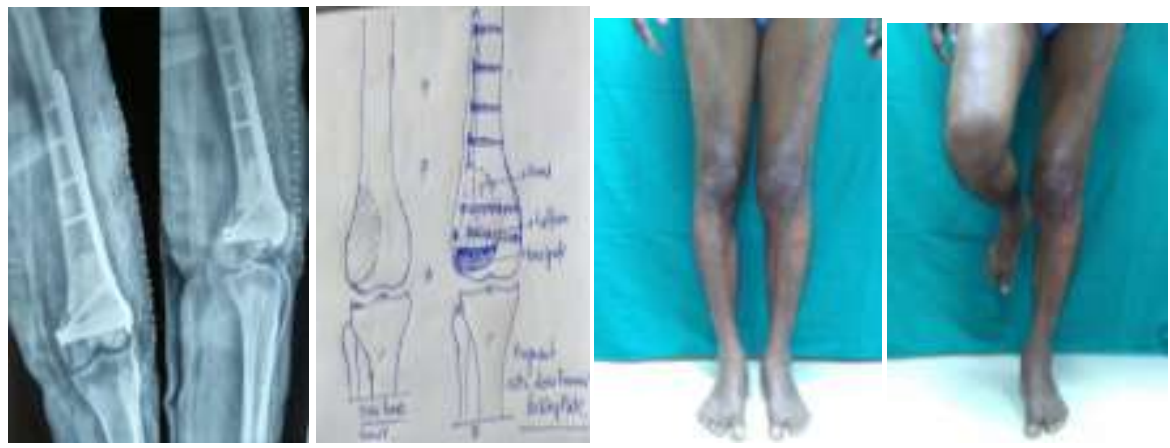

fig-8fig-9,10 -full range of movement.

They usually do notpenetrate the periosteum, but a dead space may be foundbetween cortex and the periosteum.A high power burr may beused to break the bony ridges. A pulsatile jet lavage system was used after curettage to bare the raw cancellous bone andphysically wash out tumor cells. Adjuvants such ashydrogen peroxide were used routinely.Reconstructing the defect after curettage was done with eitherbone graft alone or using a Sandwich technique depending onthe thickness of the subchondral bone along with anatomical locking plate augmentation. Sandwichtechnique included using a sheet of morselised bone graft tocover the articular cartilage. Gel foam was placed over thebone graft and cement was then used to fill the entire cavityso as to restore the anatomical shape of the bone. Closure of the soft tissue,subcutaneous tissue and skin was done in layers. Postoperatively, non-weight-bearing crutch walking was started immediately. After 2 weeks, weight bearing was allowed as tolerated. Intravenous zoledronate $(4 \mathrm{mg})$ once monthly was given for 6 months witch help in long osteoblastic bone formation as well as local control of giant cell activity.(19,20)
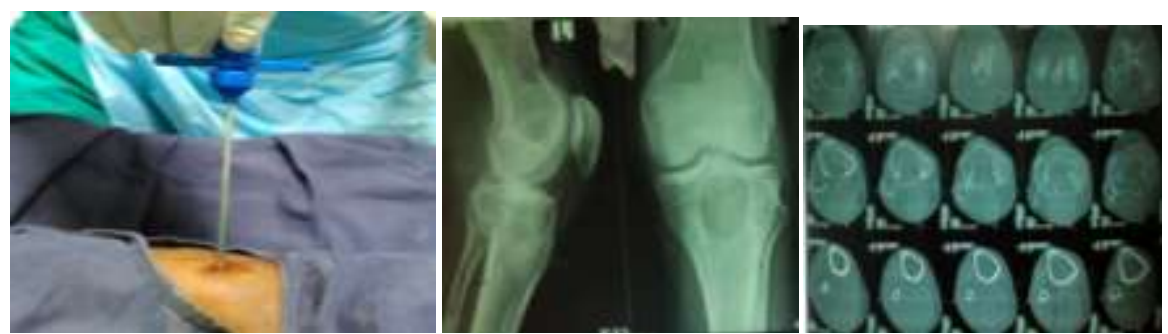

Fig-1

fig-2 fig-3

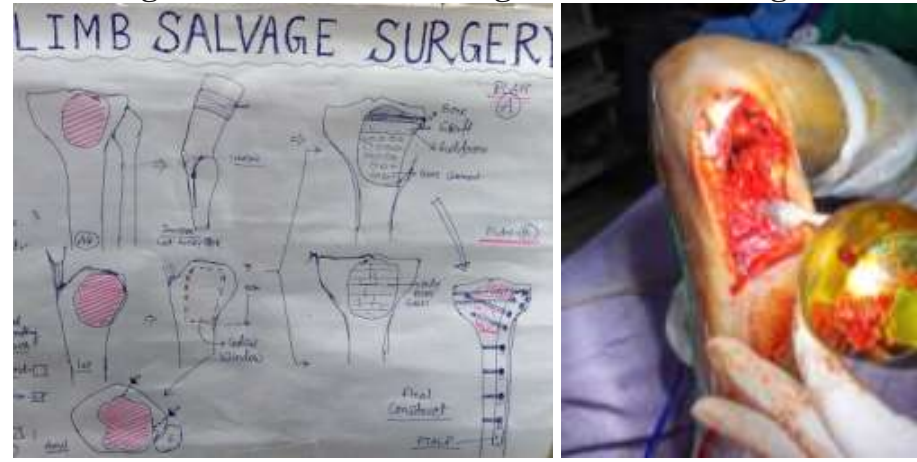

FIG-4FIG-5 

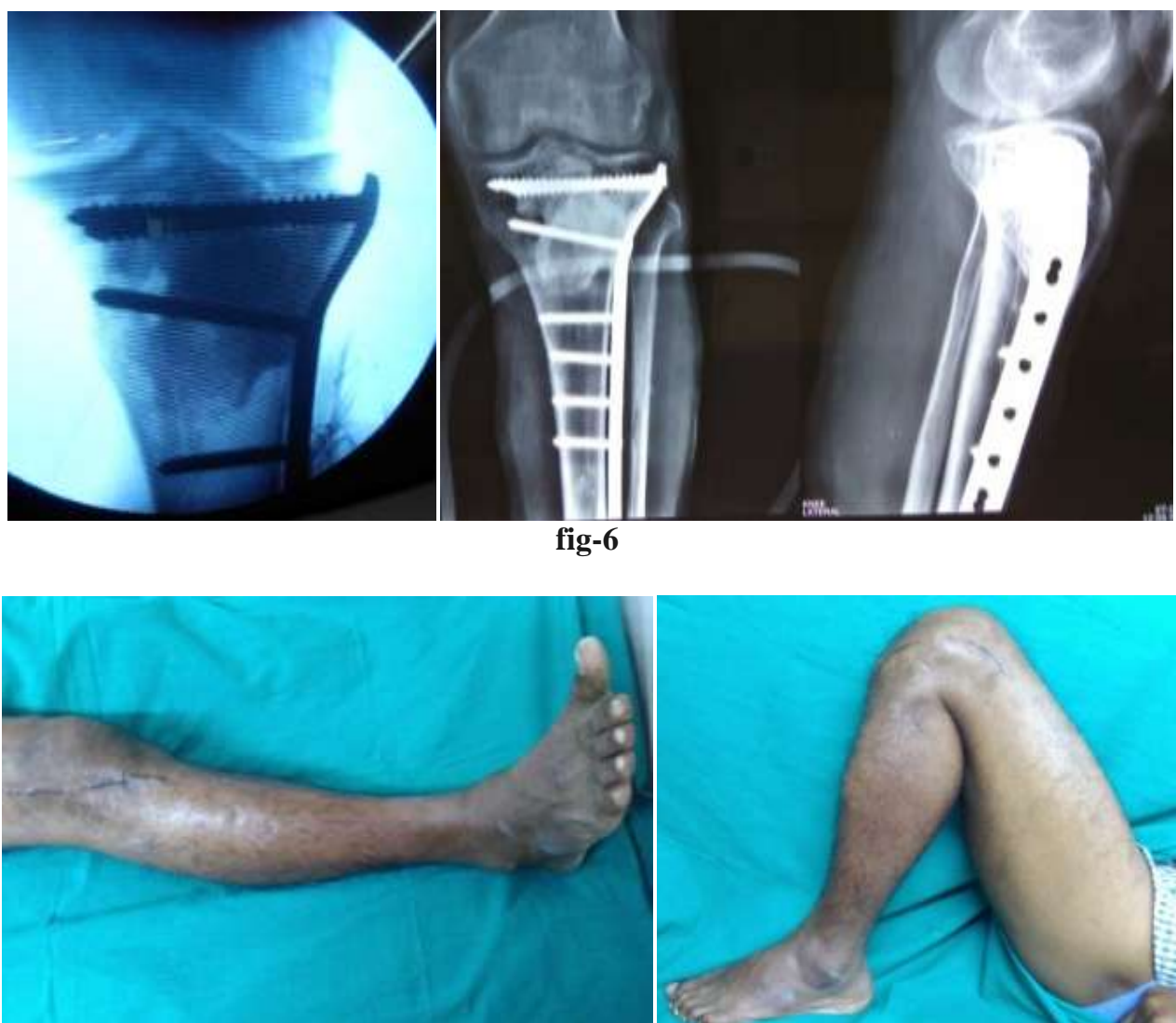

Fig7,

fig8

Fig1,2 -proximal tibial campanacci -1 lession.

Fig3- core needle biopsy

Fig-4,5,- planning of ot and intra op pic.

Fig-6,7,8 post op construct and fullrange of

motion.

\section{Result}

The mean follow up was $17.76 \pm 4.38$ months (range 12 to 31 months). The functional score preoperatively was $10.82 \pm 3.43$ (range: $0-16$ ). At 3 months post-operative follow up, it was $17.64 \pm 2.57$ (range, 15-24). At 6 months, it improved to $22.14 \pm 1.99$ (range, 19-26), which further improved to 25.73

\pm 1.42 (range, 23-27) at 9 months. The functional score at 1 year was $27 \pm 1$ (range, 25-28) and at $11 / 2$ year follow up was $27.71 \pm 0.76$ (range, 27-29). There was only 1 patient with a

follow up of more than 2 years with a functional score of 28 points as per the MSTS Score.

The data revealed that there was significant improvement inthe functional scores at each follow up visits.

Figure 1: Line Diagram showing improvement in functional scoreover time

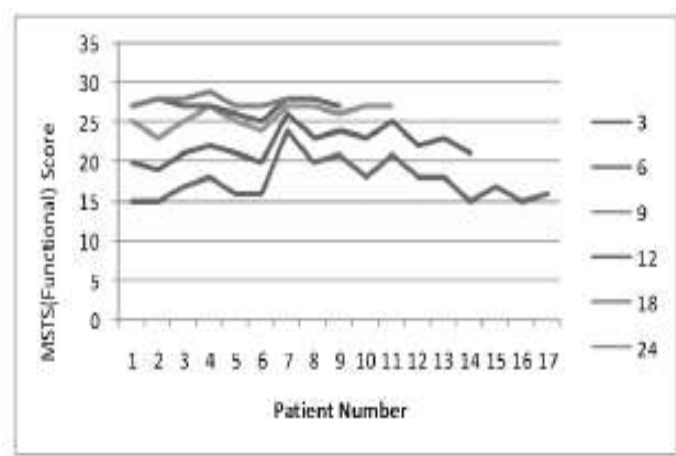


Functional evaluation of these patients was performed according to the most recent system of the Musculoskeletal Tumor Society (MSTS) .22 The pre- operative and postoperativeMSTS Score was determined and compared to study the functional outcome of the patients. The patients werefollowed for twelve to thirtyone months (mean: 17.76 months). Subgroup analysis was done by classifying the group according to age $(<30,>30)$, gender (male, female), grade of tumor, technique (bone grafting alone or sandwich technique) and primary of recurrent lesion. Statistical analysis was doneusing online calculators.MannWhitney ' $U$ ' test andANOVA test were used for subgroup analysis. Since five subgroups were analysed, the normal allowed beta error of $5 \%$ wasdivided by 5 and $\mathrm{p}$ value $<0.01$ was takento be significant.

\section{Discussion}

Treatment for GCTs around the knee include curettage with adjuvant therapy ( hydrogen peroxide, bone cement, or bone graft), andmarginal/wide resection, followed by reconstruction,arthrodesis, or megaprosthetic joint replacement.Intralesional curettage alone has a high recurrencerate of $60 \%$,(6) whereas marginal/wide resection isassociated with functional disability. Preservationof joint function is an advantage of intralesionalcurettage compared to wide resection. In our study,intralesional curettage and reconstruction with thesandwich technique,along with locking plate augmentation, achieved a good functional outcome (92.3\%).To ensure thorough curettage, adequate exposurethrough a wide cortical window is necessary, followedby breaking the bony ridges in the tumour using ahigh-power burr. Structural allograftis laid in the subchondral region and overlaid witha layer of gel foam, and the rest of the cavity is filledwith polymethylmethacrylate bone cement. Theheating effect of cement destroys remaining tumourcells.(9) The bone graft in the subchondral regionhelps maintain joint function and prevents articulardegeneration.(10)Care must be taken to prevent inadvertent corticalbreach or removal of the posterior fibroperiostealpseudocapsule during curettage.The posteriorperiosteum acts as a biological barrier, preventing theescape of bone graft or cement filled in the cavity. Therisk of neurovascular injury by phenol increases ifthe posterior periosteum is deficient. Intact posteriorperiosteum is crucial for the reconstitution of theposterior cortex, especially after bone grafting.(11)

The cavity can be reconstructed with allograft,bone cement, or calcium phosphate. The advantage ofallograft is that if it is successfully incorporated, thereconstruction is permanent, but its disadvantagesinclude difficulty in detecting recurrence and therequirement of a bone bank. The benefits of bonecement include immediate weight bearing and itscytotoxic and thermal effects to minimise the riskof recurrence, but it is associated with degenerationof articular cartilage in the subchondral region ofthe weight bearing area.(12) Applying a layer of bonegraft and gel foam not only protects the underlyingarticular cartilage from the thermal effect of the curing.

Localized lesion are said to be best treated withcurettage with bone grafting.Use of appropriate fixationmethod is recommended whenever bone stock is adequate.We used fixation in all cases fixed with anatomical locking plates.This adds stability to the bone graft and permits early mobilization and weight bearing. Use of sandwich technique has definiteindications and has been used by several authors(.15,16)The mainaim in this technique is to preserve the surviving articularcartilage by preventing damage by cement hyperthermia. Weused this technique in (8)patients. There was no case ofcollapse of the sandwich and the results were similar to casestreated with bone grafting alone. Thus, this technique can besafely used in selected cases.Meticulous planning and jamsheddi needle biopsy followed by using multiple angle scup, high speed burr,hydrogen peroxide,dental mirror,endoscopic light sources along with bone cemment Prevent reccurences.

\section{Conclusion}

The results of this study suggest that a definite andsubjectively appreciable improvement in quality of life of thepatient can be achieved by using a bone graft or sandwichtechnique reconstruction following aggressive curettage withthe use of various adjuvants. Patients of various ages and bothgender equally benefitted from surgery in terms of functionalimprovement. The tumor grade as per the Campanacci'sgrading system and surgery on primary or recurrent cases toodid not affect the functional outcome. We had one case (6\%) of recurrence in our series of 17 patients at an average followupof 14.6 months. However, a longer follow- up is requiredto comment if these outcomes are enduring and to assess therecurrence rates. Also a larger case series is needed to reportif similar results are reproducible in majority of patients.

\section{Disclosure}

No conflicts of interest were declared by the authors. 


\section{References}

[1]. Turcotte RE, Wunder JS, Isler MH, Bell RS, Schachar N, Masri BA, Moreau G, Davis AM; Canadian Sarcoma Group. Giant cell tumor of long bone: a Canadian Sarcoma Group study. Clin Orthop Relat Res.

[2]. 2002 Apr; (397): 248-58

[3]. CampanacciM. Giant cell tumor. In: GaggiA(ed) Bone and soft- tissue tumors. Springer, Bologna; 1990; 117-153

[4]. Unni KK. Dahlin's bone tumors: general aspect and data on 11087 cases, 5th edn. Lippincott-Raven, Philadelphia. 1998

[5]. Blackley HR, Wunder JS, Davis AM, White LM, Kandel R, Bell RS.

[6]. Treatment of giant-cell tumors of long bones with curettage and bonegrafting. J Bone Join Surg Am. 1999 Jun;81(6):811-20.

[7]. O'Donnell RJ, Springfield DS,Motwani HK, Ready JE, GebhardtMC, Mankin HJ. Recurrence of giant-cell tumors of the long bones after curettage and packing with cement. J Bone Joint SurgAm. 1994 Dec; 76(12): 1827- 33.

[8]. Present D, Bertoni F, Hudson T, EnnekingWF. The correlation between the radiologic staging studies and histopathologic findings in aggressive stage 3 giant cell tumor of bone. Cancer. 1986 Jan 15; 57(2): 237-44.

[9]. WardWG Sr, Li G 3rd. Customized treatment algorithm for giant cell tumor of bone: report of a series. Clin Orthop Relat Res. 2002 Apr; (397): 259-70.

[10]. Lewis VO, Wei A, Mendoza T, Primus F, Peabody T, Simon MA. Argon beam coagulation as an adjuvant for local control of giant cell tumor. Clin Orthop Relat Res. 2007 Jan; 454:192-7.

[11]. Richardson MJ, Dickinson IC. Giant cell tumor of bone. Bull Hosp Jt Dis. 1998; 57(1): 6-10.

[12]. Saglik Y, Yildiz Y, Karakas A, Ogüt H, Erekul S. Giant cell tumor of bone. Bull Hosp Jt Dis. 1999; 58(2): 98 -104.

[13]. Sung HW, Kuo DP, Shu WP, Chai YB, Liu CC, Li SM. Giant-cell tumor of bone: analysis of two hundred and eight cases in Chinese patients. J Bone Joint Surg Am. 1982 Jun; 64(5): 755-61.

[14]. Bini SA, Gill K, Johnston JO. Giant cell tumor of bone. Curettage and cement reconstruction. Clin Orthop Relat Res. 1995 Dec; (321): 245- 50.

[15]. CampanacciM, Baldini N, Boriani S, SudaneseA. Giant-cell tumor of

[16]. bone. J Bone Joint Surg Am. 1987 Jan; 69(1): 106-14.

[17]. Dreinhöfer KE, Rydholm A, Bauer HC, Kreicbergs A. Giant-cell tumours with fracture at diagnosis. Curettage and acrylic cementing in ten cases. J Bone Joint Surg Br. 1995 Mar; 77(2): 189-93.

[18]. Lackman RD, Hosalkar HS, Ogilvie CM, Torbert JT, Fox EJ. Intralesional curettage for grades II and III giant cell tumors of bone.

[19]. Clin Orthop Relat Res. 2005 Sep; 438:123-7.

[20]. Capanna R, Fabbri N, Bettelli G. Curettage of giant cell tumor of bone. The effect of surgical technique and adjuvants on

[21]. local recurrence rate. Chir Organi Mov 1990;75(1 Suppl):206.

[22]. Zhen W, Yaotian H, Songjian L, Ge L, Qingliang W. Giant-cell tumour of bone. The long-term results of treatment by

[23]. curettage and bone graft. J Bone Joint Surg Br 2004;86:212-6.

[24]. Tse LF, Wong KC, Kumta SM, Huang L, Chow TC, Griffith JF. Bisphosphonates reduce local recurrence in extremity giant

[25]. cell tumor of bone: a case-control study. Bone 2008;42:68-73.

[26]. Chang SS, Suratwala SJ, Jung KM, Doppelt JD, Zhang HZ, Blaine TA, et al. Bisphosphonates may reduce recurrence in giant

[27]. Kanamori M, Ohmori K. Curettage and radiotherapy of giant cell tumor. J Orthopaedic Surgery 2005; $13(2)$ : $171-173$.

[28]. Eckardt JJ, Grogan TJ. Giant cell tumor of bone. Clin Orthop 1986; 204: 45- 58.

[29]. Turcotte RE, Wunder JS, Isler MH, et al. Giant cell tumor of bone: A Canadian Sarcoma Group Study. Clin Orthop 2002; 397: 248-258.

[30]. Laustin GS, Jensin PK, Schiodt T. Local recurrences in giant cell tumor of long bones. Int Orthop 1996; 20 : 172-176.

[31]. Davis AM, Bell RS, Badley EM, et al. Evaluating functionl outcome in patients with lower extremity sarcoma. Clin Orthop 1999; 358: 90-100.

[32]. Lavoie S, Turcotte RE, Birthiaume MJ, et al. The arthrogenic effects for the treatment of (GCT) of the knee. J Bone Joint Surg 1998; 80: 14-16

[33]. Trieb K, Bitzan P, Dominkus M, et al. Giant cell tumor of long bone. J Bone Joint Surg 2000; 82: 1360-1361. 